УДК 373.3.015.31:172-044.352

DOI:

Оксана Шквир, доктор педагогічних наук, доцент, професор кафедри педагогіки Хмельницької гуманітарно-педагогічної академії

\title{
ПІДГОТОВКА МАЙБУТНІХ УЧИТЕЛІВ ПОЧАТКОВОЇ ШКОЛИ ДО ВИХОВАННЯ ЕТНІЧНОЇ ТОЛЕРАНТНОСТІ
}

У статті акиентовано увагу на проблемі етнічної толерантності як якісного показника формування іміджу Украӥни. Визначено, що одним із шляхів формування етнічної толерантності громадян нашої краӥни $е$ підготовка майбутніх учителів до толерантного виховання школярів, зокрема учнів початкових класів. Уточнено сутність понять “толерантність", “етнічна толерантність". Запропоновано авторське визначення поняття "підготовка майбутніх учителів початкової школи до виховання етнічної толерантності". Окреслено завдання, зміст, методи та форми виховання етнічної толерантності в молодших школярів. Визначено педагогічні умови підготовки майбутніх учителів початкової школи до виховання етнічноі толерантності.

Ключові слова: толерантність; етнічна толерантність; інтолерантне ставлення; підготовка майбутніх учителів до виховання етнічної толерантності; почуття толерантності; педагогічні умови підготовки майбутніх учителів до виховання етнічної толерантності.

Jim. 9.

Oksana Shkvyr, Doctor of Sciences(Pedagogy), Associate Professor, Professor of the Pedagogy Department Khmelnytskiy Humanitarian-Pedagogical Academy

\section{TRAINING OF THE FUTURE PRIMARY SCHOOL TEACHERS FOR EDUCATION OF ETHNIC TOLERANCE}

The article focuses on the problem of ethnic tolerance as a qualitative indicator of forming the image of Ukraine. It has been determined that one of the ways of forming ethnic tolerance of the citizens of our country is the training of the future teachers for the tolerant education of pupils, in particular primary school pupils. The essence of the concepts "tolerance", "ethnic tolerance" has been clarified. The author definition of the concept "training of the future primary school teachers for the education of ethnic tolerance" has been offered. It is a system of scientifically grounded actions in the general pedagogical process of a higher education institution, aimed at developing the students' humanistic values, a sense of tolerance; mastering a complex of special psychological-pedagogical knowledge and skills, which ensures high efficiency of the teacher's educational activity and their self-development. The tasks, content, methods and forms of ethnic tolerance education of junior schoolchildren to be mastered by the future primary school teachers in the process of vocational training have been outlined. According to the results of the study of the scientific-pedagogical literature and the survey of university teachers, the pedagogical conditions for the training of the future primary school teachers for the education of ethnic tolerance have been determined: motivation of the future teachers to realize the value of a tolerant position in the interethnic environment; the students' awareness of the importance and meaning of ethnic tolerance as an important personal quality; mastering of the future teachers in various ways of organizing subject-subjective interaction with primary school pupils; establishing a dialogue and polylogue with all children in order to overcome negative stereotypes and prejudices; creation of tolerant educational environment in higher educational institution that is conducive to developing a sense of tolerance for the future teachers and the acquisition of individual experiences of tolerant behavior in the course of inter-ethnic communication. It is stated that the questions of substantiation of the effectiveness of the mentioned pedagogical conditions require further scientific development.

Keywords: tolerance; ethnic tolerance; intolerant attitude; training of the future teachers for the education of ethnic tolerance; feeling of tolerance; pedagogical conditions for the training of the future teachers for the education of ethnic tolerance.

П остановка проблеми. У світлі демократичного розвитку громадянського суспільства нашоїдержави,іїорієнтаціїна інтеграцію у європейське співтовариство на перше місце виходять питання дотримання прав, свобод людини у полікультурному та поліетнічному середовищі.
Слід зазначити, що в Україні сформувалася своєрідна етнонаціональна палітра з кількісною перевагою корінного українського етносу, наявністю різноманітних етнічних меншин. Останніх у країні проживає понад 130. Статистичні дані Всеукраїнського перепису населення 2001 р. свідчать, що частка етнічних 


\section{ПІДГОТОВКА МАЙБУТНІХ УЧИТЕЛІВ ПОЧАТКОВОӤ ШКОЛИ ДОВИХОВАННЯ ЕТНІЧНОЇТОЛЕРАНТНОСТІ}

меншин становить 22,2 \% від усього населення країни [6].

Однак образ, в якому постає Україна сьогодні, $\epsilon$ далеко не тим, яким його хоче бачити європейська спільнота. За останні роки збільшилися прояви агресії на міжетнічному грунті, загострилися міжкультурні протиріччя. Також слід констатувати збільшення випадків неодноразового зауваження міжнародних інституцій щодо наявних проявів нетолерантності та ксенофобії до іноземців в українському суспільстві [2].

Все це актуалізує проблему етнічної толерантності як якісного показника формування іміджу України.

Одним із шляхів формування етнічної толерантності громадян нашої країни $є$ підготовка майбутніх учителів до толерантного виховання школярів, зокрема учнів початкових класів. Адже в українських школах навчаються діти різних національностей, які розмовляють різними мовами, їхні сім'ї ходять до різних церков. У Концепції Нової української школи зазначається, що вітчизняну школу необхідно перетворити на важіль соціальної рівності та згуртованості [5]. Саме вчитель початкових класів має великі можливості для утвердження загальнолюдських та національних цінностей. I якщо принципи толерантності (гуманізм, демократизм, дитиноцентризм) будуть основою особистої позиції вчителя у виборі змісту, методів і форм виховної роботи, то він зможе сформувати етнічну толерантність і в учнів початкових класів.

Аналіз останніх досліджень. Дослідженню проблем професійної підготовки педагогічних кадрів в Україні завжди приділялась належна увага. Так теоретичні та методичні засади неперервної професійної освіти знайшли відображення в працях С. Гончаренка, Н. Ничкало, Л. Романишиної, С. Сисоєвої та ін. У дослідженнях О. Дубасенюк, О. Пєхоти, Л. Пуховської та ін. розкрита роль освітніх інновацій у професійній підготовці майбутніх учителів через формування толерантного освітнього середовища. У працях Ш. Амонашвілі, I. Беха, О. Савченко, В. Сухомлинського та ін. виокремлено принципи педагогіки толерантності та визначені особливості підготовки майбутніх учителів до виховання молодших школярів.

Однак проблема етнічної толерантності та особливостей підготовки майбутніх учителів початкової школи до виховання етнічної толерантності досліджена недостатньо.

Мета статті полягає в уточненні змісту понять “толерантність" $i$ “етнічна толерантність” та визначенні особливостей підготовки майбутніх учителів початкової школи до виховання етнічної толерантності.

Виклад основного матеріалу. Слід зазначити, що проблема виховання толерантності, зокрема етнічної, є досить новою, оскільки лише наприкінці 90-х рр. минулого століття у вітчизняній педагогічній літературі почали з'являтися відповідні публікації.

Толерантність (від лат. Tolerantia - терпіння) відсутність чи послаблення реагування на якийсь несприятливий чинник у результаті зниження чутливості до його дії [7]. Толерантність терпимість до чужого способу життя, поведінки, чужих звичаїв, почуттів, вірувань, думок, ідей $[1$, $17]$.

Погоджуємося з О. Савченко, що толерантність - це неодмінна риса шляхетної особистості й важлива ознака цивілізованого демократичного суспільства [8]. Ця риса передбачає повагу до іншого, прийняття його особливостей та визнання його прав. Та це не означає, що права одних людей чи соціальних груп можуть бути реалізовані за рахунок ущемлення прав інших. Толерантність покликана гармонізувати різні позиції для досягнення взаєморозуміння, ефективної суспільної взаємодії. Формула толерантності "Усі ми різні - усі ми рівні" $[8,5]$

Толерантність розглядається у контексті таких понять, як “визнання”, “прийняття", “розуміння”. Визнання - це здатність бачити в іншому саме іншого як носія інших цінностей, іншої логіки мислення, інших форм поведінки. Прийняття - це позитивне ставлення до таких відмінностей. Розуміння - це вміння бачити іншого із середини, здатність поглянути на його світ водночас 3 двох точок зору: власної та його [4, 12].

Важливу роль в активізації уваги науковців до проблеми толерантності відіграло прийняття в європейському і світовому просторі низки міжнародних документів, у яких підкреслювалась універсальна роль цього феномена. Зокрема, це "Декларація принципів толерантності" (ЮНЕСКО, 1995 р.), Доповідь ЮНЕСКО “Освіта для ХХІ століття” (1996р.), у якій було визначено чотири ціннісні виміри життя у глобалізованому світі: уміння жити разом, уміння вчитися, уміння діяти, уміння бути. Особливий інтерес для освітян має “Декларація тисячоліття ООН” (2000 р.), у якій визначено шість фундаментальних цінностей людства: свобода, рівність, солідарність, терпимість, повага до природи, загальний обов'язок $[9,5]$.

Методологічною основою толерантності є усвідомлення особою необхідності доброзичливого 


\section{ПІДГОТОВКА МАЙБУТНІХ УЧИТЕЛІВ ПОЧАТКОВОЇ ШКОЛИ ДОВИХОВАННЯ ЕТНІЧНОЇ ТОЛЕРАНТНОСТІ}

або стриманого ставлення до відмінностей між людьми у широкому розумінні, уникнення нетерпимості, поцінування різноманітностейу природі, культурі, релігії, у людських стосунках $[9,5]$.

Справжня толерантність проявляється в прагненні зрозуміти тих, хто відрізняється від нас мовою, віросповіданням, способами життя тощо, за умови, звісно, що цей спосіб життя не принижує інших членів суспільства. Однак слід розрізняти толерантну поведінку та рабську терпимість. Те, що порушує загальнолюдську мораль не повинно сприйматись толерантно.

Будь-яке полікультурне суспільство, зокрема й українське, якщо воно не керується принципами толерантності, $є$ дуже вразливим. Таким суспільством можна маніпулювати, в ньому легко посіяти розбрат, запалити вогнище насильства [8, 5]. Толерантність має гармонізувати суспільство, не допустити приниження окремих його членів, зокрема й представників меншин.

Етнічна толерантність - це готовність особистості терпимо сприймати ті чи інші явища національного життя і міжетнічних стосунків [7].

Етнічна толерантність - це психологічна якість (риса характеру), опосередкована соціальними нормами. Вона характеризується готовністю до співпраці, взаємовигідного партнерства на основі загальнолюдських цінностей; готовністю до культурного взаємообміну і взаємозбагачення; здатністю до взаємної емпатії; установкою на діалог із метою досягнення більшого взаєморозуміння між людьми різних національностей та етнічних груп $[1,17-18]$.

Етнічна толерантність - не вроджена якість, іiі треба виховувати поступово і наполегливо. У закладі загальної середньої освіти це слід робити вже 3 перших класів. Виховує педагог, його вчинки, судження, оцінювання інших. Головне його завдання навчити дітей бути терпимими до інших, незалежно від їхньої національності, мови, релігійних переконань. Етнічна толерантність передбачає гуманізм, демократизм, дитиноцентризм, розуміння та захист інтересів дитини.

Однак стереотип несприйняття інакшості значною мірою притаманний самим педагогам. Саме нетерпимість дорослих до “інакшоі” дитини породжує нетерпиме, інтолерантне ставлення до неї однолітків.

Тому необхідно готувати майбутніх учителів початкової школи до етнічного виховання молодших школярів. Під такою підготовкою ми розуміємо систему науково обгрунтованих дій у загальному педагогічному процесі закладу вищої освіти, спрямовану на розвиток у студентів гуманістичних цінностей, почуття толерантності; оволодіння комплексом спеціальних психологопедагогічних знань і умінь, що забезпечує високу результативність виховної діяльності вчителя та його саморозвиток.

Під гуманістичними цінностями ми розуміємо культивування педагогами у своїх взаєминах із оточуючими терпимості, доброзичливості, ввічливості, щирості, стриманості, милосердя, справедливості. Для розвитку цих якостей необхідно організовувати в закладі вищої освіти суб 'єкт-суб' єктну взаємодію учасників навчання на засадах діалогу, партнерства. Як свідчать спеціальні дослідження, особливо ефективними $є$ різні види тренінгів, що дають змогу студентам засвоїти стратегії комунікативної толерантності та застерегти їх від використання негативних педагогічних стереотипів $[9,7]$.

Необхідно у майбутніх педагогів розвивати почуття толерантності як професійно важливу рису їх особистісно-професійного розвитку, що характеризується відмовою від дивергенції та бажанням сприяти етнічному синтезу, який, у свою чергу, базується на здатності конструктивно сприймати досягнення інших культур [3]. Його розвитку сприяють освітнє середовище 3ВО, власний приклад толерантної поведінки викладачів у процесі спілкування зі студентами та оточуючими; залучення студентів до різних видів практики та суспільно-корисної діяльності.

У процесі підготовки студенти мають усвідомити, що головне завдання педагога - це навчити вихованців чути і поважати думку інших, приймати їхню інакшість, необразливо обгрунтовувати власну позицію, поступатися, домовлятися, взаємодіяти. Для цього треба підвищувати загальну культуру студентів, розширювати їхній культурний простір у діалозі мистецтв. Чим ширший культурний кругозір людини, тим більше передумов для розуміння інших $[8,7]$. Також майбутній педагог має навчитися уникати крайнощів націоналізму й етноцентризму, а натомість цілеспрямовано формувати у вихованців терпимість, безконфліктність, національну ідентичність і повагу до культур інших народів. О. Савченко зазначає, що педагогічна толерантність несумісна із байдужістю і відстороненим ставленням учителя до будь-яких форм насильства над дітьми $[9,5]$. Результатом толерантного виховання є виховання толерантної дитини. Показниками сформованості етнічної толерантності як риси характеру є:

- готовність до того, що всі люди різні;

- готовність сприймати людей такими, якими вони $\epsilon$, не намагаючись змінити в них те, що нам не подобається; 


\section{ПІДГОТОВКА МАЙБУТНІХ УЧИТЕЛІВ ПОЧАТКОВОӤ ШКОЛИ ДО ВИХОВАННЯ ЕТНІЧНОЇ ТОЛЕРАНТНОСТІ}

- готовність цінувати в кожній людині особистість і поважати їі думки, почуття, переконання незалежно від того, чи збігаються вони 3 нашими [4, 12 - 13].

Майбутні вчителі мають засвоїти, що етнічна толерантність проявляється через слова, погляд, жести педагога, що мимоволі формує ставлення дитини до іншого. Тому важливим є оволодіння студентами педагогічною технікою, методами та формами виховання етнічної толерантності у молодших школярів, до яких відносимо спеціальні бесіди, приклади, диспути, тренінги, створення проблемних ситуацій, благодійні акції, рольові ігри, колективні творчі справи, зустрічі та ін. У процесі підготовки майбутні вчителі мають навчитися шукати і знаходити різноманітні приклади, використовувати життєві ситуації аби показати дітям, що бувають різні точки зору і кожна з них має право на існування, якщо не суперечить основним цінностям нашого суспільства $[8,8]$.

У процесі підготовки майбутніх учителів важливо створити педагогічні умови, що сприяють формуванню готовності до виховання етнічної толерантності в молодших школярів. На основі вивчення науково-педагогічної літератури, опитування вчителів початкової школи нами визначено низку таких педагогічних умов. Із метою визначення серед них більш важливих була створена експертна комісія у складі 12 чоловік із числа викладачів 3ВО, які відзначили серед запропонованих такі умови:

1. Мотивування майбутніх учителів до усвідомлення цінності толерантної позиції у міжетнічному середовищі, іiі органічного зв'язку із людиноцентризмом, гуманізмом педагогічної професії.

2. Усвідомлення студентами сутності та значення етнічної толерантності як важливої особистісної якості.

3. Оволодіння майбутніми вчителями різними способами організації суб'єкт-суб'єктної взаємодії 3 учнями початкових класів; налагодження діалогу і полілогу з усіма дітьми 3 метою подолання негативних стереотипів і упереджень, налаштування їх на позитивне сприйняття іншого, інакшого; усвідомлення правила толерантності "Усі різні - рівні".

4. Створення у закладі вищої освіти толерантного освітнього середовища, сприятливого для розвитку в майбутніх учителів почуття толерантності та набуття індивідуального досвіду толерантної поведінки у міжетнічному спілкуванні.

Висновки. Отже, ідея етнічної толерантності пов'язана, насамперед, із євроінтеграційними прагненнями України, оскільки шанування прав і свобод кожної людини є важливою ознакою європейської спільноти.

Підготовка майбутніх учителів початкових класів до виховання етнічної толерантності передбачає формування у майбутніх фахівців гуманістичних цінностей, розвиток почуття толерантності, оволодіння змістом, методами і формами виховання етнічної толерантності в учнів початкових класів.

Ефективності зазначеної підготовки сприяють визначені нами педагогічні умови: мотивування майбутніх учителів до усвідомлення цінності толерантної позиції у міжетнічному середовищі; усвідомлення студентами сутності та значення етнічної толерантності як важливої особистісної якості; оволодіння майбутніми вчителями різними способами організації суб'єкт-суб'єктної взаємодії 3 учнями початкових класів; налагодження діалогу і полілогу з усіма дітьми 3 метою подолання негативних стереотипів і упереджень; створення у закладі вищої освіти толерантного освітнього середовища, сприятливого для розвитку в майбутніх учителів почуття толерантності та набуття індивідуального досвіду толерантної поведінки у міжетнічному спілкуванні.

Подальших наукових розвідок потребує питання обгрунтування визначених педагогічних умов.

\section{ЛІТЕРАТУРА}

1. Ангеліна Е. О. Етнічна толерантність старшокласників. Психологічні науки: Збірник наукових праць Приватного вищого навчального закладу “Донецький інститут соціальної освіти”. Том 2. Випуск 10 (91). 2013. С. 16 - 20.

2. Бакальчук В. О. Тенденції етнокультурної толерантності в українському суспільстві. Стратегічні пріоритети. 2007. № 4. С. 69 - 75.

3. Данько Т. Соціокультурні витоки екстремізму. Правий екстремізм і толерантність: 3 досвіду України та Німеччини. Київ: Заповіт, 2008. С. $33-35$.

4. Джерела духовності. Упровадження принципів гуманної педагогіки в практику роботи початкової школи / Упоряд. Л.Г. Дмитренко. Харків: Вид. група “Основа”, 2015. 142 с.

5. Концепція Нової української школи. Схвалена колегією Міністерства освіти і науки України 27 жовтня 2016 року. URL: https:/www.kmu.gov.ua/ storage/app/media/reforms/ukrainska-shkolacompressed.pdf. (дата звернення 16.09.2019).

6. Про кількість та склад населення за підсумками Всеукраїнського перепису населення 2001 p. URL: http://2001.ukrcensus.gov.ua/results/ general/nationality/. (дата звернення 10.09.2019). 


\section{ПІДГОТОВКА МАЙБУТНІХ УЧИТЕЛІВ ПОЧАТКОВОЇ ШКОЛИ ДОВИХОВАННЯ ЕТНІЧНОЇТОЛЕРАНТНОСТІ}

7. Психология: Словарь / [авт.-сост. А. В. Петровский, М. Г. Ярошевский]. 2-е изд., испр. и доп. Москва: Политиздат, 1990. 494 с.

8. Савченко О., Андрусич О. Педагогіка толерантності - вимога часу. Дошкільне виховання. № 10. 2014. С. 4 - 8 .

9. Савченко О. Толерантність як цінність шкільної освіти: методичний аспект. Початкова школа. № 9. 2014. С. 4 - 7.

\section{REFERENCES}

1. Anhelina, E. O. (2013). Etnichna tolerantnist starshoklasnykiv. Psykholohichni nauky: Zbirnyk naukovykh prats Pryvatnoho vyshchoho navchalnoho zakladu "Donetskyi instytut sotsialnoyi osvity" [Ethnic Tolerance of High School Students. Psychological Sciences: Collection of Scientific Papers of the Private Higher Educational Institution "Donetsk Institute of Social Education"]. Vol. 2. issue 10 (91). pp. $16-$ 20. [in Ukrainian].

2. Bakalchuk, V. O. (2007). Tendentsii etnokulturnoi tolerantnosti v ukrainskomu suspilstvi Stratehichni priorytety [Trends of Ethnocultural Tolerance in Ukrainian Society. Strategic Priorities]. No. 4. pp. $69-75$. [in Ukrainian].

3. Danko, T. (2008). Sotsiokulturni vytoky ekstremizmu. Pravyi ekstremizm i tolerantnist: $z$ dosvidu Ukrainy ta Nimechchyny [Sociocultural Origins of Extremism. Right Extremism and Tolerance: from the Experience of Ukraine and Germany]. Kyiv, pp. 33 - 35. [in Ukrainian].

4. Dzherela dukhovnosti. Uprovadzhennia pryntsypiv humannoi pedahohiky v praktyku roboty pochatkovoi shkoly [Sources of Spirituality. Implementation of the Principles of Humane Pedagogy in the Practice of Primary School]. (Ed.). L.H. Dmytrenko. Kharkiv, 2015. 142 p. [in Ukrainian].

5. Kontseptsiya Novoi ukrainskoi shkoly. Skhvalena kolehiyeyu Ministerstva osvity i nauky Ukrainy 27 zhovtnia 2016 roku [The Concept of the New Ukrainian School. Approved by the Board of the Ministry of Education and Science of Ukraine on October 27, 2016]. Available at: https:// www.kmu.gov.ua/storage/app/media/reforms/ ukrainska-shkola-compressed.pdf. (accessed 16 Sept.2019). [in Ukrainian].

6. Pro kilkist ta sklad naselennia za pidsumkamy Vseukrainskoho perepysu naselennia 2001 r. [About the Number and Composition of the Population According to the 2001 All-Ukrainian Population Census]. Available at: http://2001.ukrcensus.gov.ua/ results/general/nationality/. (accessed 10 Sept.2019). [in Ukrainian].

7. Psikhologiya: Slovar [Psychology: Dictionary]. (Ed.).A. V. Petrovskii, M. G. Yaroshevskii. Moscov, 1990. 494 p. [in Russian].

8. Savchenko, O. \& Andrusych, O. (2014). Pedahohika tolerantnosti - vymoha chasu. Doshkilne vykhovannia [Pedagogy of Tolerance Requirement of the Time. Pre-School Education]. No. 10. pp. 4 - 8. [in Ukrainian].

9. Savchenko, O. (2014). Tolerantnist yak tsinnist shkilnoi osvity: metodychnyi aspekt. Pochatkova shkola [Tolerance as a Value of School Education: Methodical Aspect. Primary School]. No. 9. pp. 4 - 7. [in Ukrainian].

Стаття надійшла до редакції 07.10.2019

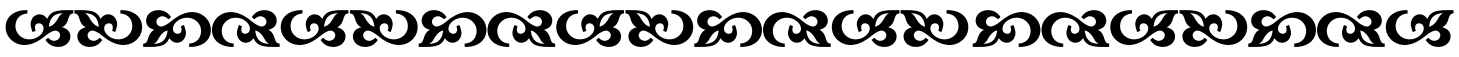

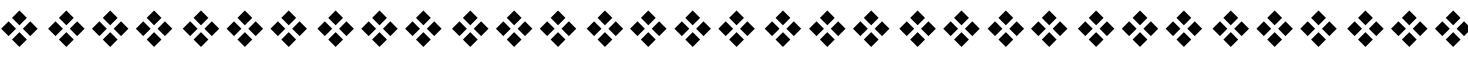

“Слово - наш найважливіший педагогічний інструмент, його нічим не заміниш".

Василь Сухомлинський

український педагог

"Тарні манери має той, хто найменшу қільқість людей ставить у незручне становище”.

Dжонатан Свіббт

ірландський письменник

"Яке призначення людини? Бути нею!"

Станіслав Сжи Аєи

польський поет, білособ, письменник-сатирик

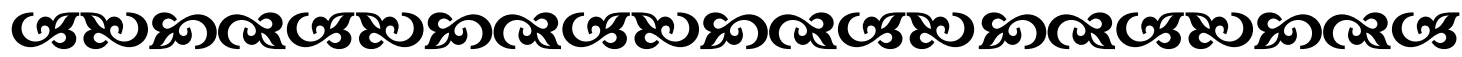

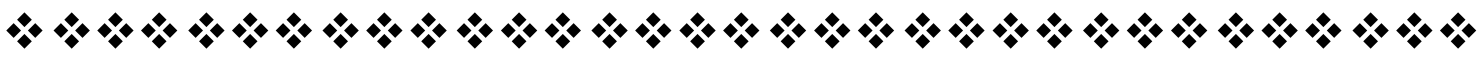

Молодь і ринок №1 (180), 2020 